\title{
Factors affecting the dynamics of the North Karelian/ Oulu Ice Lobe, Central Finland, during the last deglaciation - a LiDAR and DEM interpretation of subglacial lineation patterns
}

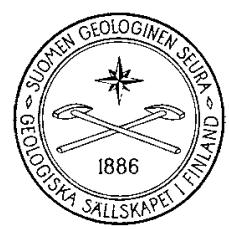

VERTAISARVIOITU KOLLEGIALT GRANSKAD PEER-REVIEWED
www.tsv.fi/tunnus

\author{
Timna NikarmaA ${ }^{\mathrm{I}^{*}}$, Juha Pekka Lunkka ${ }^{\mathrm{I}}$ and Niko Putkinen ${ }^{2}$ \\ ${ }^{1}$ Oulu Mining School, P.O. Box 3000, FI-90014 University of Oulu, Finland \\ ${ }^{2}$ Geological Survey of Finland, P.O. Box 97, FI-67101 Kokkola, Finland
}

\begin{abstract}
The SIS (Scandinavian Ice Sheet) became divided into several active, semi-independent ice lobes during the last deglaciation ca $13000-10000$ years ago. The largest of them, the North Karelian/Oulu Ice Lobe (NKIL/OIL), covered vast areas in central Finland and in northwest Russian Karelia. This paper studies the behaviour and subglacial conditions of the NKIL/OIL with the inversion modelling method. The method is based on the identification and interpretation of mapped glacigenic streamlined lineations, formed during active flow stages of the NKIL/OIL. DEM and LiDAR data on lineations was obtained from seven subsets in different zones of the NKIL/OIL. Results indicate that the NKIL/OIL dynamics were strongly affected by pre-existing Quaternary sediment thickness, bedrock lithology, structures and topography. Due to these factors, the NKIL/ OIL operated through several flow corridors and had several retreat and re-advance cycles throughout its life span.
\end{abstract}

Keywords: LiDAR, Scandinavian ice sheet, Oulu, Northern Ostrobothnia, glacial lineations, streamlined formations, Mega-scale glacial lineations, Kalevala end moraine

* Corresponding author (email: tiina.nikarmaa@oulu.fi)

Editorial handling: Pertti Sarala (pertti.sarala@gtk.fi) 


\section{Introduction}

In the Late Weichselian, the centre of the Scandinavian Ice Sheet (SIS) was located in the Scandinavian mountains. It advanced to central Finland and beyond ca 25000 years ago. As the ice margin reached its last glacial maximum position 15000-18000 years ago in the east, the whole land area of Finland was covered by the SIS, with its most eastern ice lobes covering northwest Russia (e.g. Lunkka et al., 2001; Svendsen et al., 2004; Larsen et al., 2006).

During the last deglaciation the SIS became divided into several active ice lobes separated by passive ice areas. At least five major active ice lobes existed in Finland during the last deglaciation (Punkari, 1980). They behaved semi-independently in space and time and, therefore, the marginal moraines formed in front of adjacent ice lobes can be metachronous (Punkari \& Boulton, 1995).

One of the ice lobes was the North Karelian Ice Lobe (NKIL), which subsequently evolved into the Oulu Ice Lobe (OIL) as deglaciation progressed (Aario \& Forsström, 1979; Kleman et al., 1997; Boulton et al., 2001; Putkinen \& Lunkka, 2008). The NKIL/OIL covered vast areas in central and eastern Finland $\left(57000 \mathrm{~km}^{2}\right.$ in total) and extended to northwest Russia (Fig. 1). A major landform related to the NKIL is the Kalevala end moraine, which marks the terminus of the NKIL in the south and the east. This end moraine was most likely deposited soon after the Younger Dryas (Putkinen, 2011) and it can be followed for hundreds of kilometres from eastern Finland to Russian Karelia (Punkari \& Boulton, 1995; Punkari, 1997). In Russian Karelia, the NKIL terminated in a large glacial lake east of Kalevala end moraine (Putkinen \&Lunkka, 2008; Putkinen, 2011).

The White Sea Ice Lobe (WSIL), which subsequently evolved into the Kuusamo Ice Lobe (KIL), co-existed north of the NKIL/OIL (e.g. Punkari \& Boulton, 1995; Boulton et al., 2001; Punkari, 1985; 1997). The WSIL/KIL covered large areas of southern and central Lapland, northwest Russia and the White Sea. The Taivalkoski-Hossa interlobate complex was formed between these two ice lobes, the WSIL and the NKIL/OIL.

The southern and southwestern margins of the NKIL/OIL are marked by an interlobate system extending from the Northern Ostrobothnia seashore (in the vicinity of Raahe) to southeast, through Vihanti, Piippola, Pyhäntä, Vieremä, Iisalmi and towards Siilinjärvi to confront the Finnish Lake District Ice Lobe (FLDL) region. From Siilinjärvi, a relatively large interlobate esker, formed between the FLDL and the NKIL/ OIL, runs towards Ylämylly and Joensuu and the terminus of the NKIL/OIL (Fig. 2).

The terminus zone of the NKIL is a complex formation consisting of glaciofluvial deltas with large outwash plains and kettle holes, and end moraine ridges bulldozed by active wet-based glacier. The arc-shaped chain of formations marks the Kalevala end moraine, which extends from Joensuu across the Karelian territories in Finland and Russia and to Kalevala to the north. This formation is previously described in detail, e.g. by Punkari (1985), Ekman \& Iljin (1991), Rainio (1995), Putkinen \& Lunkka (2008), Putkinen (2011).

In general, terrestrial ice streams tend to fan out in their terminal areas. Boulton et al. (2001) identify the main factors controlling the behaviour and flow of terrestrial ice sheets and streams as ice divides (principal and subsidiary), basal freezing and melting, and passive ice areas (slow-flowing zones) inside or between fast-flowing ice streams. The main controlling factors affecting spatial ice sheet behaviour are bedrock type and its structure, water basins and their depth, previously deposited subglacial sediments and their thickness, as well as landscape topography. Stokes et al. (2007) propose that sticky spots under ice (i.e. bedrock bumps, till-free areas, areas of rigid till and freeze-on of subglacial meltwater) influence the behaviour of ice streams by inhibiting and controlling ice flow. Porewater and groundwater in subglacial sediments also have an effect on ice streaming and vice versa (e.g. Ravier et al., 2014; Boulton \& Zatsepin, 2006). 
The primary aim of this study is to get more information on the dynamics of the NKIL/OIL and its spatial and temporal subglacial conditions. The ambition is also to gain in-depth knowledge of when and where streamlined formations were evolving during the last deglaciation, which took place in the area covered by the ice lobes ca $13000-10000$ years ago. The focus is on the mapping and identification of glacigenic, streamlined landforms formed during active flow stages of the NKIL/OIL. Using LiDAR DEM data, it is possible to acquire detailed data to interpret glacial landforms (orientation, morphology, location). This inversion modelling approach is used to reconstruct the behaviour of the former ice lobe, and the direction and velocity of its ice flow.

The study is on the Oulu/North Karelian ice lobe (NKIL/OIL) as a whole, with seven subsets within the ice lobe. The subsets are situated in different zones within the NKIL/OIL (Fig. 2). In the NKIL/OIL area, topography varies considerably between western and eastern regions and therefore the area is also an ideal study on how different regional factors affect the behaviour of an ice lobe.

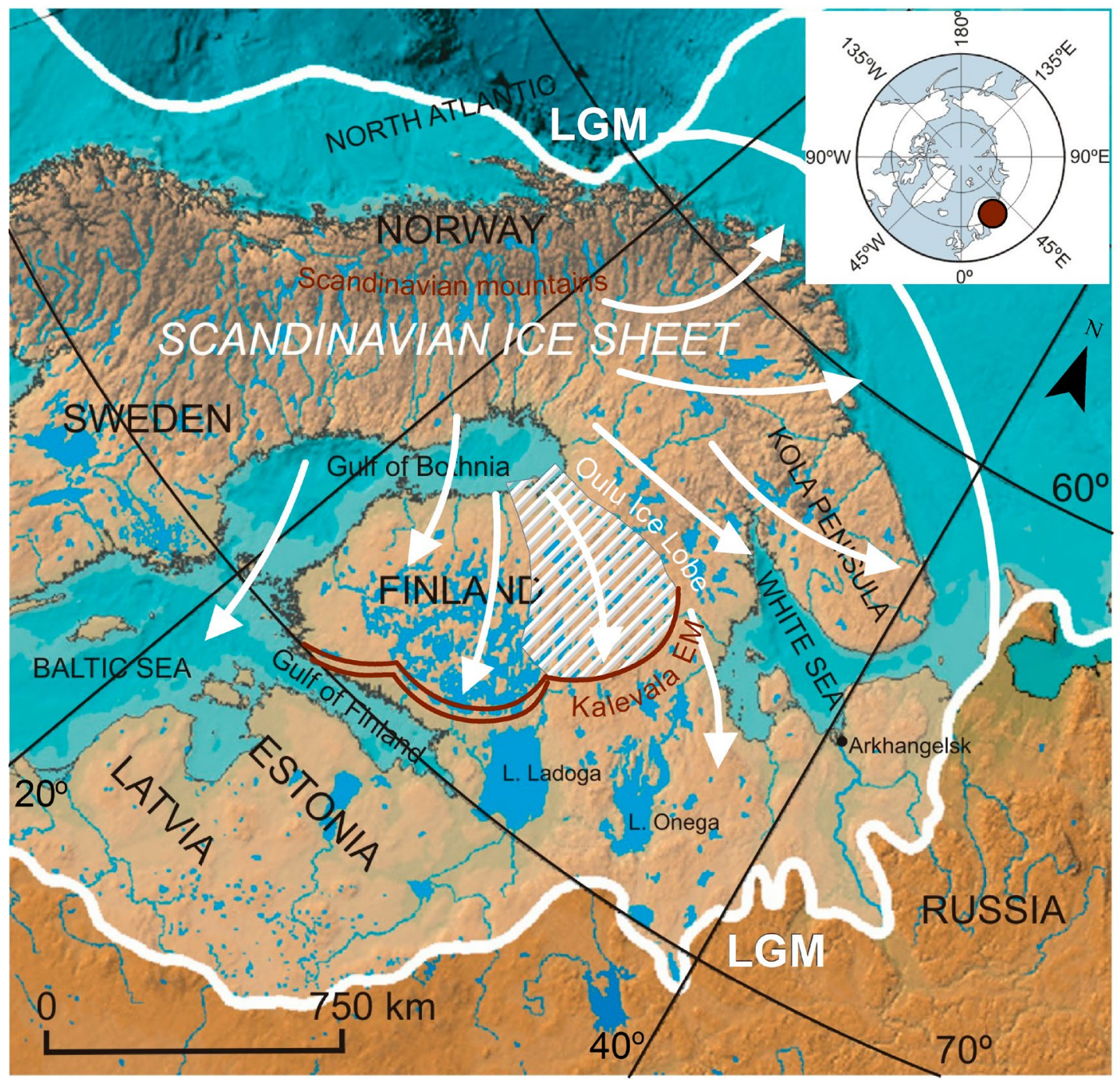

Figure 1. Scandinavian ice streams (white arrows) during the last deglaciation (after Punkari 1985, 1997; Punkari \& Boulton 1995) and the location of the NKIL/OIL (white lined area). LGM = Last glacial maximum. Kalevala EM = Kalevala end moraine. Figure modified after Lunkka et al., 2012. 


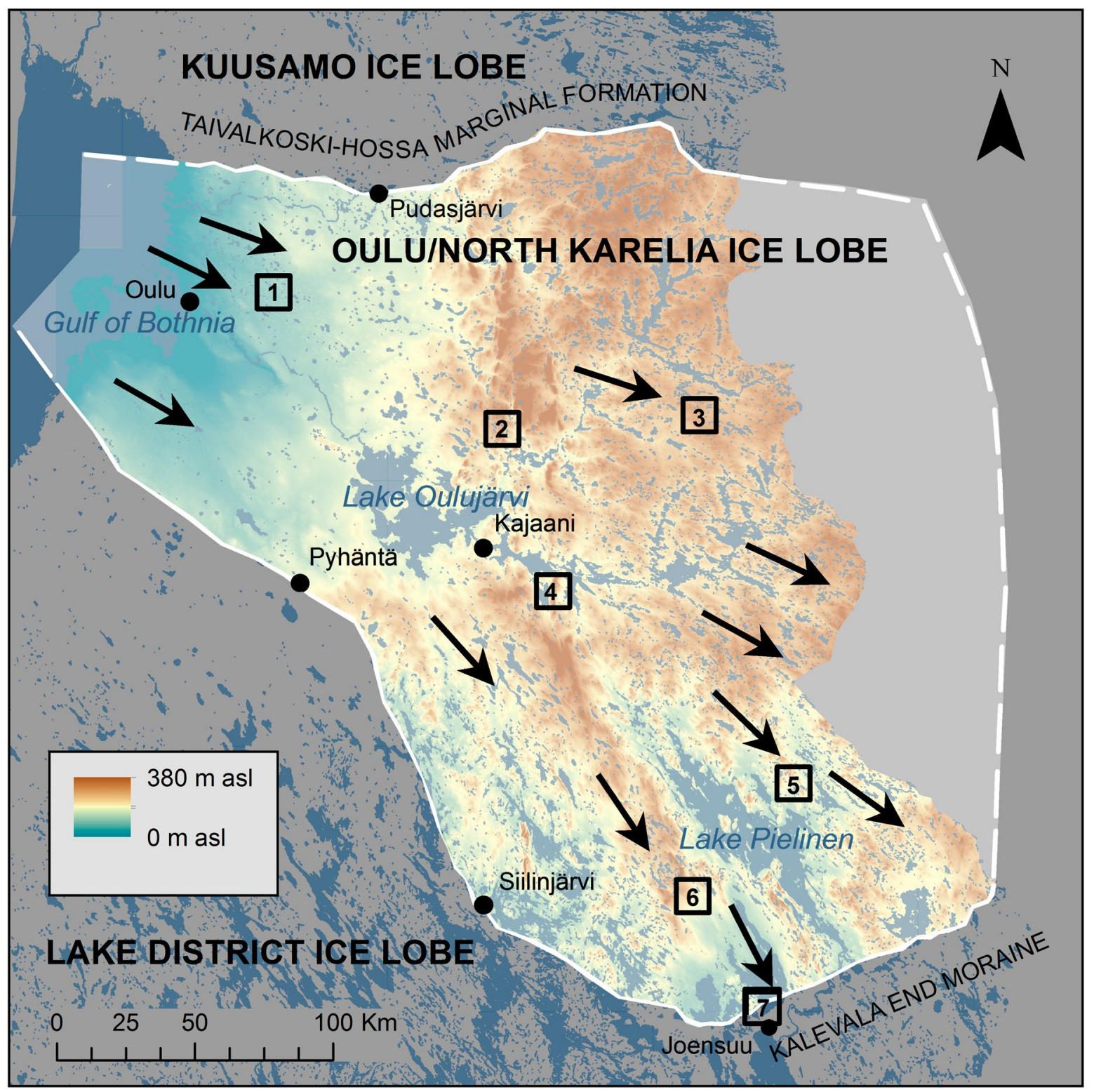

Figure 2. Dimensions of the NKIL/OIL and the locations of the seven subsets/insets (squares 1-7) chosen for flowset mapping. Black arrows indicate ice flow direction and their location fast flow areas. Base map: NLS of Finland (1/2017).

\section{Topography and bedrock of the study area}

The western part of the NKIL is characterized by lowlands and gently sloping terrain with no major bedrock escarpments. Glacial and postglacial deposits are thick. Large areas in the west were subaquatic during and after the ice retreated from the region, so the topography is smoother than in the supra-aquatic areas of the eastern parts of the NKIL. The highest shoreline of the postglacial lakes in central Finland can be traced approximately along the Jurmu-Puolanka-Kajaani line (Ojala et al., 2013). 
Figure 3. Different zones of an ice lobe: onset, trunk and offset/ terminus. Modified after Stokes \& Clark (2003).

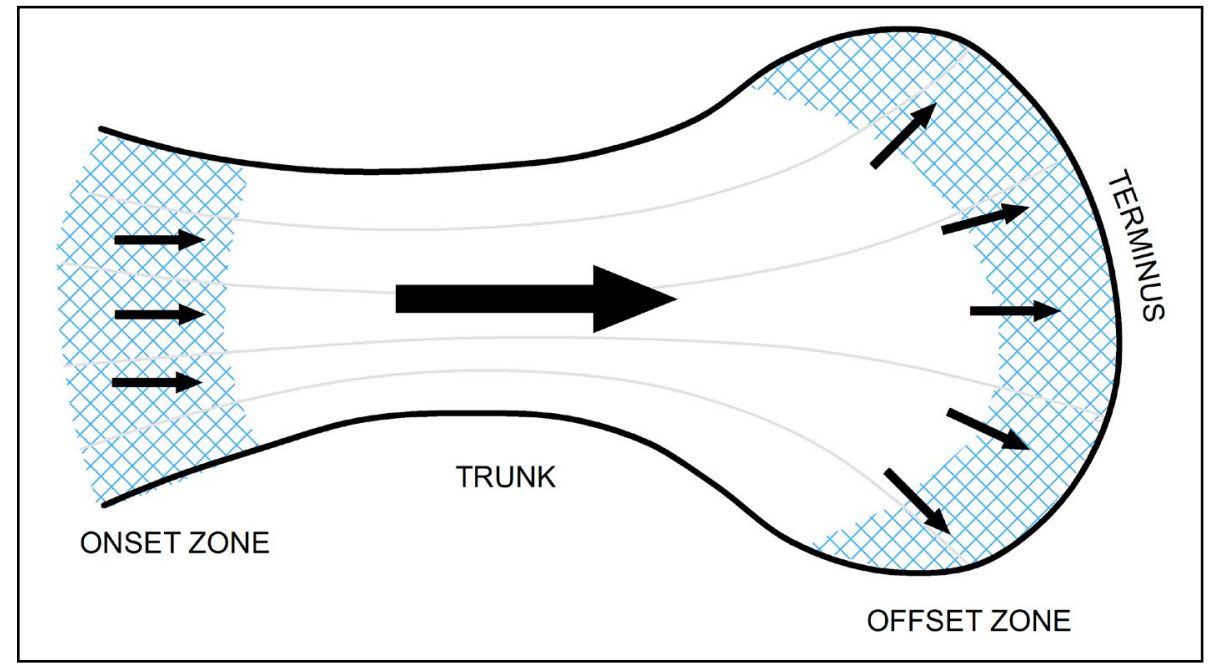

The middle part of the NKIL is characterized by high topographical variation and hard quartzite hills control the landscape. The contact of the Archaean and Proterozoic bedrock runs approximately from northwest to southeast across the study area, Archaean rocks appearing in the east. The quartzite hills adjacent to the Archaean bedrock are remnants of ancient mountains formed during the Svecofennian orogeny 1900 million years ago (Lehtinen et al., 1998).

Terrain in the eastern part of the NKIL area is higher than in the western part. Large lakes dominate the eastern terrain and the bedrock in the uplands area is composed of granodiorite, tonalite and gneiss.

\section{Theory}

To acquire information on the behaviour of former ice lobes in formerly glaciated areas, it is essential to diagnose subglacial features in the landscape and relate them to ice flow dynamics (inversion modelling). It has been commonly proposed (e.g. Aario, 1977; Clark, 2010; Eyles et al., 2016) that streamlined features, drumlins (or drumlinoids) and (mega)flutings, form a continuum under an ice stream and depend on subglacial conditions and ice flow velocity. Subglacial landforms seem to develop from larger or transverse formations into longitudinal, more elongated and narrow formations downstream. In any particular landscape, landform features which indicate a former ice stream operation of the same glacier system include convergent onset zones and flow patterns, abrupt lateral margins, and elongated subglacial landforms. Typically, the velocity of a terrestrial ice stream is at its highest in the trunk zone, increasing in the onset zone and decreasing towards the offset zone where the ice flow diverges (Stokes \& Clark, 2003) (Fig. 3).

Understanding how subglacial lineations (e.g. drumlins) originated under ice is important when depicting conditions in the ice-bed interface. A number of diverse theories have been proposed, which fall into two main categories: the depositional and the erosional origin of streamlined landforms (e.g. drumlins). Also theories combining erosion, deformation and deposition have been suggested (Möller \& Dowling, 2016). In this paper, the focus is on some of the most recent theories on the genesis of streamlined formations.

An example of a depositional theory is the socalled instability theory (Fowler, 2010; Stokes et al., 2013). It proposes that instabilities, a wave-like movement of ice, substrate, and uneven deposition of sediment at the ice-bed interface cause drumlin accumulation.

The Erodent Layer Hypothesis (ELH) was recently introduced by Eyles et al. (2016). It suggests 
that drumlins form primarily by erosional processes in areas of pre-existing sediments, deposited during earlier phases of glaciation. Texturally weaker sediments would have been eroded by an 'erodent layer', a thin film of subglacial debris between ice and bed, permafrost or bedrock, while stiffer spots of sediments would have remained and been shaped into streamlined landforms. The theory also suggests the existence of an active erodent stream capable of abrading and transporting a large load of sediment, permafrost and stones within a softbedded deformation bed under ice. -

\section{Methods and datasets}

\subsection{LiDAR/DEM datasets:}

The land surface of the study area is full of lineations, which were grouped into flowsets. Mapping was carried out by using the elevation data DEM (Digital Elevation Model), produced by the National Land Survey of Finland (NLS) from LiDAR (Light Detection and Ranging) data. The LiDAR-point density is at least 0.5 points per square metre and the vertical precision is between 0.3 and 1.0 metres. The resolution, therefore, enables precise imaging of landforms. The LiDAR point cloud data was pre-processed by the GTK (Geological Survey of Finland) to remove noise and produce a digital elevation model (DEM) with a $2 \mathrm{~m}$ resolution. The coordinate system used in this process is EUREF FIN / ETRS-TM35FIN. Currently, the LiDAR and the $2 \mathrm{~m}$-DEM do not cover the whole study area, so quaternary geological maps and outcrop data (both produced by the GTK) were also used in addition to LiDAR mapping.

The NLS's Digital Elevation Data tiles were stitched together in the GTK 3D-laboratory to create a uniform Mosaic Raster Dataset. A multidimensional hillshading (MDOW) was produced simultaneously. An angle of illumination of $30^{\circ}$ and a vertical exaggeration of $\mathrm{x} 5$ were used to better highlight glacigenic landforms.

\subsection{Landform mapping}

The glacial lineations studied were mapped manually using ESRI's (Environmental Systems Research Institute) ArcMap 10.3 software and the GTK's database classification for landforms (Putkinen et al., 2017, Supplementary file 2; this volume). The lineation data in ArcMap-format is saved in the GTK's personal geodatabase.

Streamlined features were mapped as polylines and areas (e.g. drumlin uplands representing large relict sediment bodies typically with lineated surfaces) as polygons. Glacial lineations were mapped into five different classes: drumlins, rock drumlins, flutings, megaflutings and pre-crags. Lengths of lineations were measured and then stored in the database. All lineations were identified and classified according to their geomorphological shape, length and orientation. The classification of linear formations was based on a lineation's length-width ratio, which was visually estimated. Through valleys and crescent troughs were mapped as polylines representing fast flowing glacier erosion on bedrock. (Through valleys are bedrock troughs eroded by subglacial wet sediment-water mixture. They are closely related to bedrock proximal crescent troughs.) Ambiguous landforms which could not be classified into any category were coded more generally as 'glacially lineated terrain'. The relative age of lineations and occurrences of palimpsests were also listed.

\section{Results and interpretation}

Glacial geomorphological formations across the NKIL are presented below in seven inset figures (Figs. 4-10). Mega-scale glacial lineations (MSGLs) reveal that the main ice flow direction in the NKIL area was from west-northwest to east-southeast, fanning out towards the south-southeast in its southern marginal zone and towards the east or eastnortheast in its eastern marginal zone. 


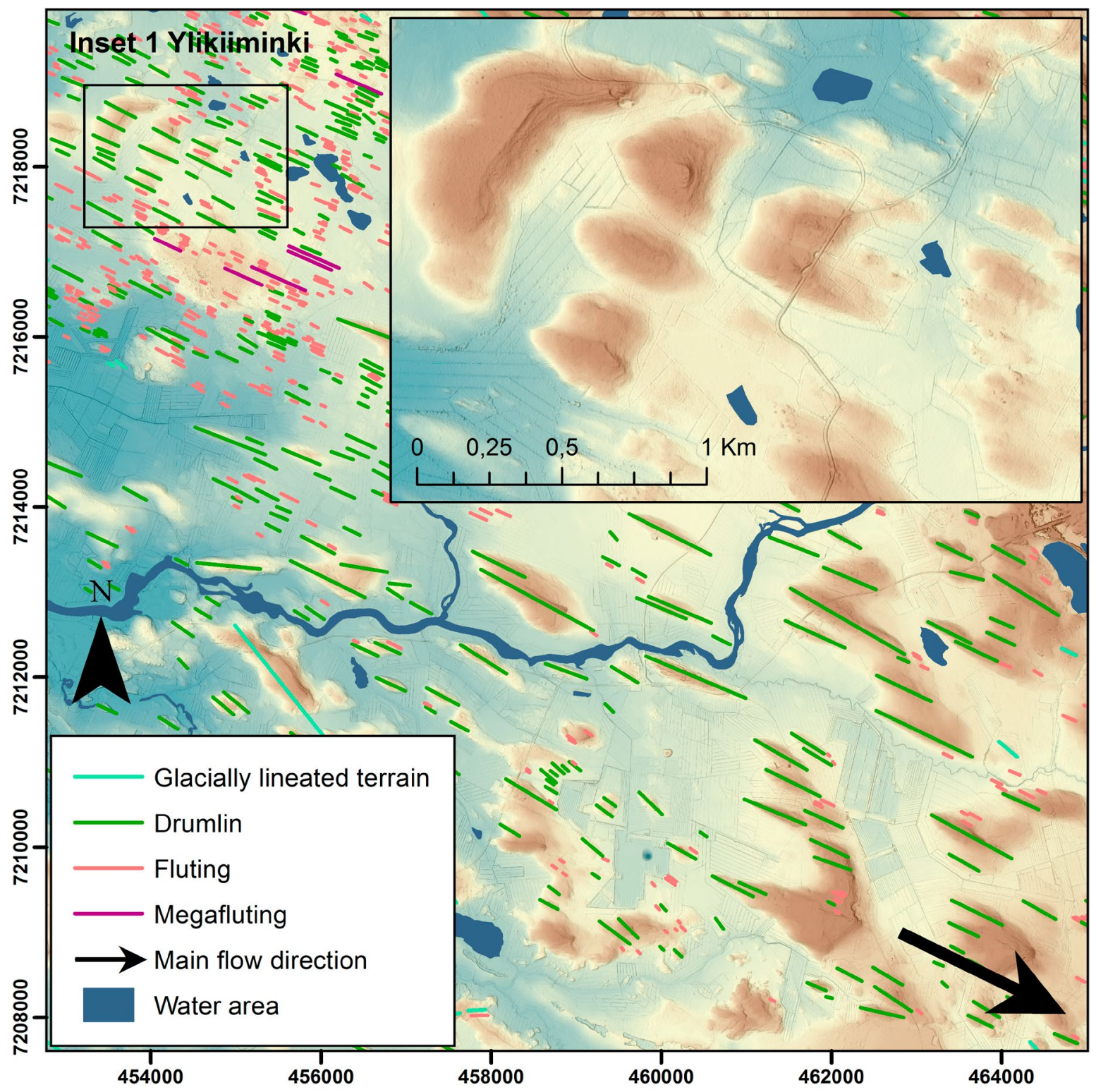

Figure 4. Inset 1, Ylikiiminki.

\subsection{Inset 1: Ylikiiminki, Northern Ostrobothnia}

\subsubsection{Description}

Inset area 1 (Fig. 4) is situated in western Finland, ca $25 \mathrm{~km}$ east of the city of Oulu. Bedrock there is composed of mica schist and greywacke, with some mafic vulcanite and quartzite to the northwest. The topography of the area is flat and it lies ca 60-70 m above the present sea level (asl). Only the highest MSGLs are at 80 to $90 \mathrm{~m}$ asl. There are no extensive bedrock outcrops in the area.

LiDAR imageries show relatively thick Quaternary sediment cover in area 1. During post-glacial times, first the Ancylus Lake and 
then Litorina Sea sediments covered the terrain (cf. Donner, 1995) until the area became glacioisostatically uplifted. This exposed it to littoral currents and wave activity, which reworked glacigenic sediments, including primary glacigenic landforms. As a consequence, classifying an individual landform can be difficult.

Area 1's dominating features are drumlins. The mean length of the drumlins measured is 292 metres (min $57 \mathrm{~m}$, max $1666 \mathrm{~m}$ ). For flutings, it is 90 metres (min $22 \mathrm{~m}, \max 329 \mathrm{~m})$ and, for megaflutings, 551 metres ( $\min 332 \mathrm{~m}$, max $687 \mathrm{~m})$.

Drumlins and megaflutings are orientated from west-northwest to east-southeast. Older flow sets also appear, which indicate an ice flow from northwest to southeast across this region. These older flow sets are overrun by younger ice flow from west-northwest, forming a palimpsest landscape (Fig. 4).

\subsubsection{Interpretation}

Area 1 is characterised by landform evolution from ribbed moraines to drumlins, indicating a glacier base evolution continuum from a cold-based glacier (ribbed moraines) to a warm-based, fast flowing glacier (drumlins) (Aario, 1979; Eyles el al., 2016). This continuum represents the onset zone of the NKIL/OIL.

A thick sediment cover ensures a soft-bed environment, contributing to fast ice flow in most of the inset region. Drumlins and megaflutings indicate fast ice flow velocities in $2.5-5.0 \mathrm{~km}$ wide ice flow corridors at Isosuo-Hirvisuo, OnkamoHannusperä, Kiiminki-Ylikiiminki, around Sanginjoki and a southern flow corridor in TikkaperäTemmes (see flow corridors in Fig. 11). It seems that topographically higher bedrock in the northeastern parts of the area steered glacier flow southwards.

\subsection{Inset 2: Hietavaara (Paltamo), Central Finland}

\subsubsection{Description}

Inset area 2 (Fig. 5) is situated $120 \mathrm{~km}$ east-southeast of Oulu. The altitude of the area ranges from $170 \mathrm{~m}$ asl in lowlands to $280-290 \mathrm{~m}$ asl in the uplands area. North-south trending quartzite escarpment dominates the topography. Bedrock in the western side of the quartzite hills is migmatite gneiss and, in the east, schists. Bedrock structures (e.g. faults) are typically orientated from north to south. Sediment cover is thick on both sides of the quartzite hills but very thin on top of the quartzite escarpment.

Megaflutings were formed at lower altitudes on the lee side of the hills (Fig. 5A). Their mean length is 925 metres ( $\min 408 \mathrm{~m}$, $\max 1978 \mathrm{~m}$ ). The mean length of small needle-shaped flutings and drumlins in area 2 is 112 metres $(\min 24 \mathrm{~m}, \max 684 \mathrm{~m})$ and 369 metres (min $94 \mathrm{~m}$, max $1905 \mathrm{~m}$ ) respectively. The most abundant features are small flutings.

\subsubsection{Interpretation}

Orientations and patterns of lineation in area 2 indicate that the main ice flow direction was from west-northwest to east-southeast.

Flutings at the top of the quartzite escarpment would have been formed when fast moving, wetbased ice flowed over thin sediment cover. The flutings developed in extending cavities behind the obstacles (also called crag-and-tails).

In some locations, funnel-shaped through valleys were formed by subglacial ice, water or erodent stream cutting their way through and cleaning faults in the bedrock (Figs 5A and 5B). 


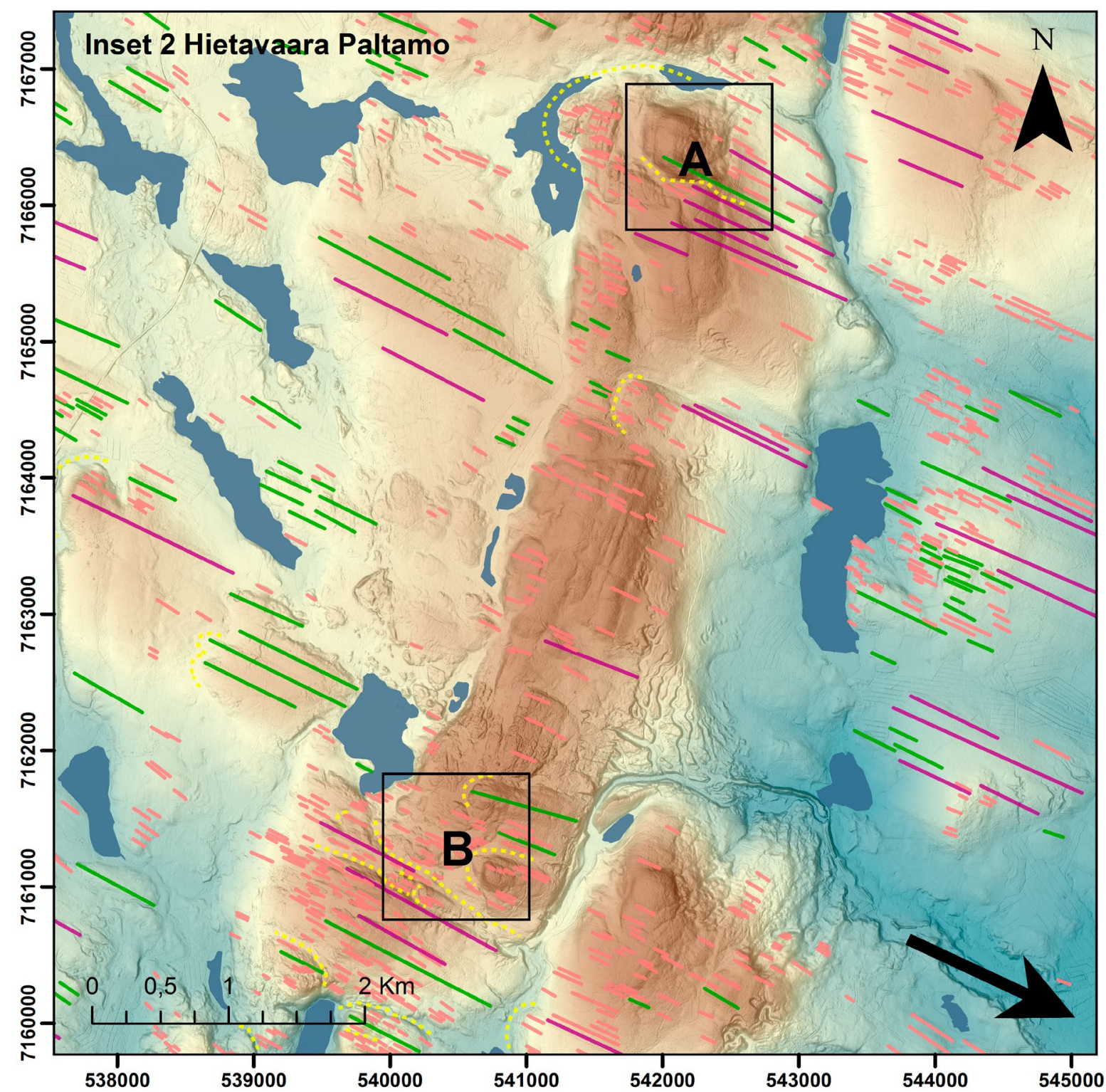

Figure 5. Inset 2, Hietavaara (Paltamo). For legend see Figure 4. 


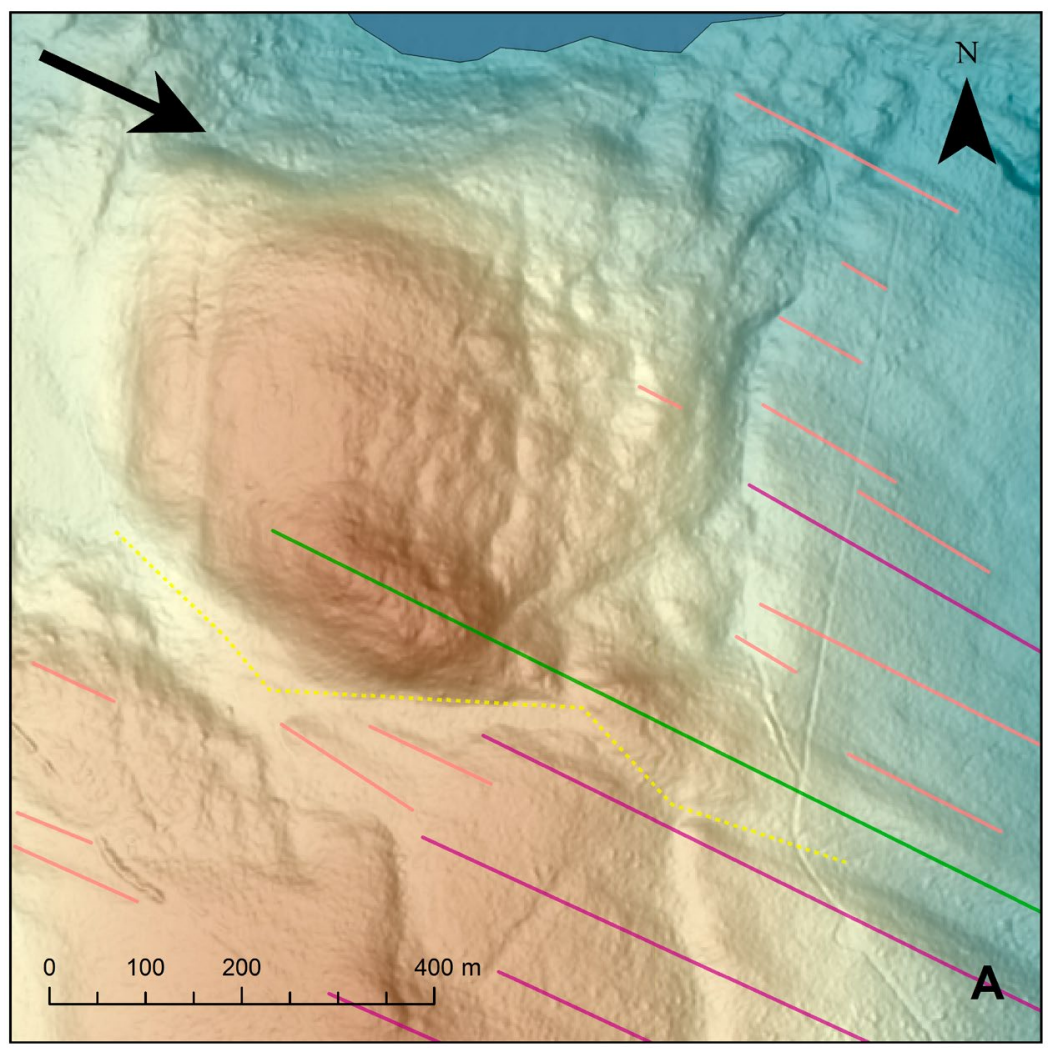

Figure 5A.

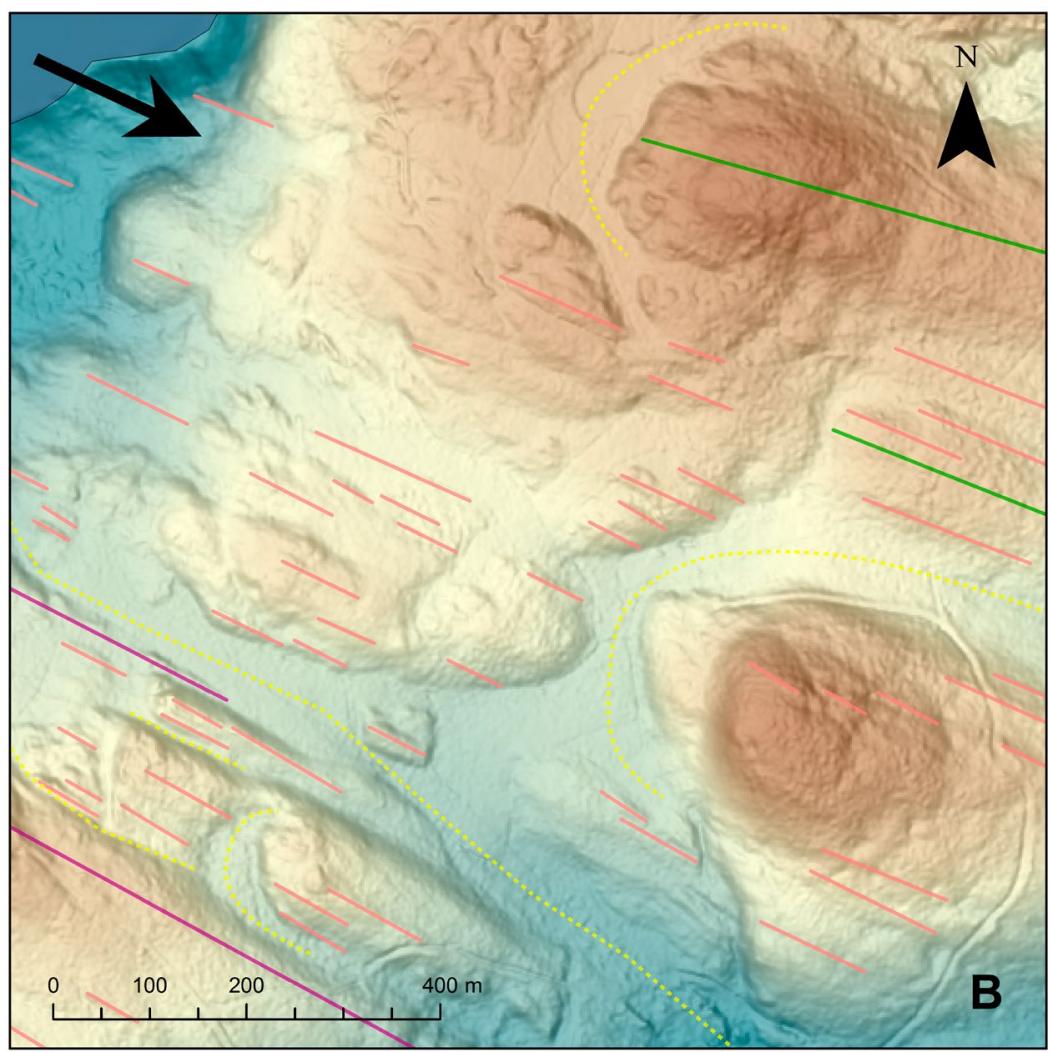

Figure 5B. 


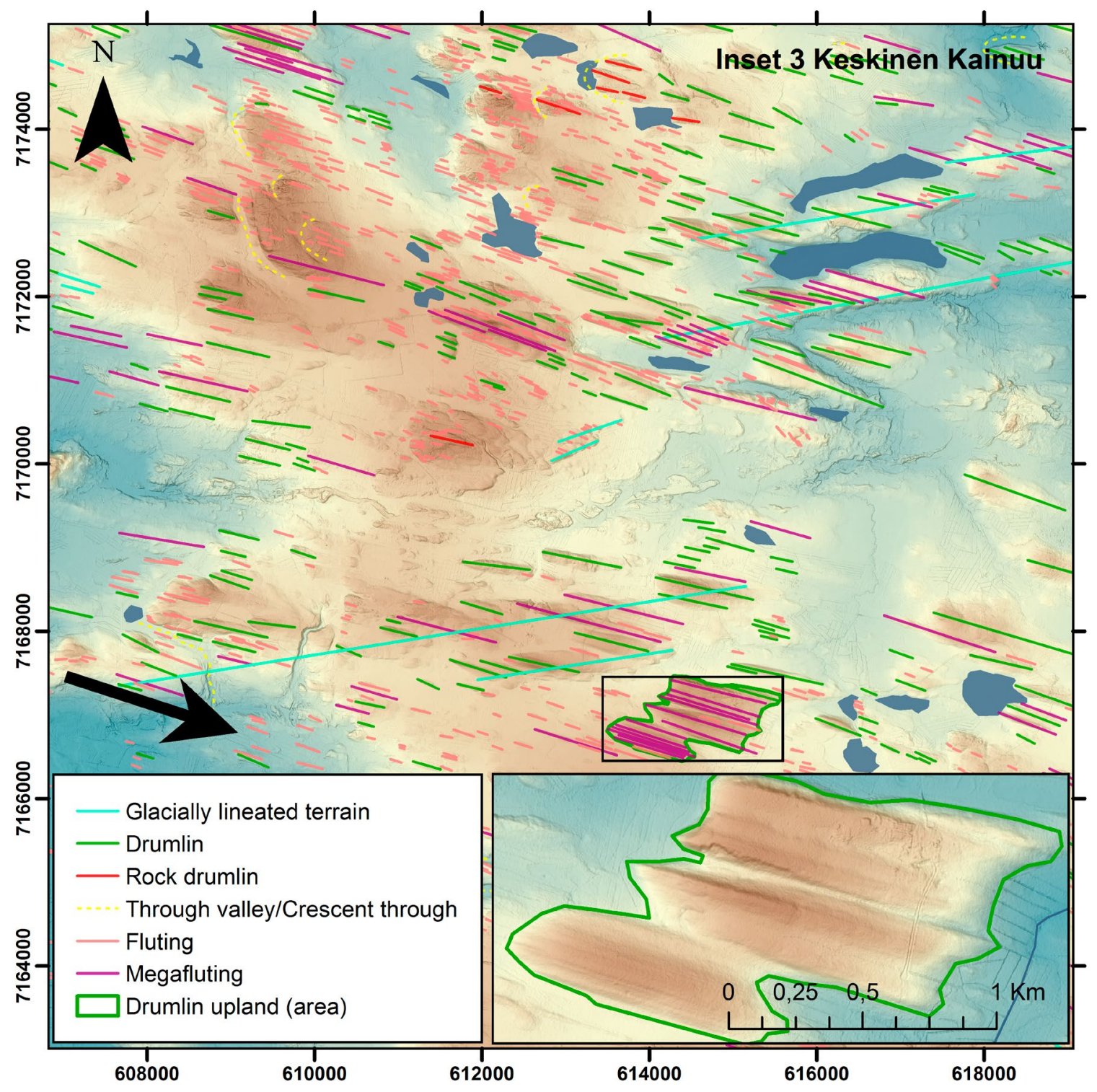

Figure 6. Inset 3, Keskinen, Kainuu. Drumlin upland indicates a cloning continuum from drumlins to megaflutings.

\subsection{Inset 3: Keskinen, Kainuu}

\subsubsection{Description}

Inset area 3 is located in Kainuu, adjacent to the Russian border. The mean altitude of the area is around $200 \mathrm{~m}$ asl and the highest bedrock hills reach $250-260 \mathrm{~m}$ asl. The bedrock mainly consists of migmatite gneiss. Granite, granodiorite, tonalite, quartzdiorite and amphibolite also occur in the western and southern parts of the area.

In inset area 3, drumlins and megaflutings are long and narrow. The drumlins are more abundant and their mean length is 408 metres ( $\mathrm{min} 84 \mathrm{~m}$, max $1796 \mathrm{~m}$ ). Megaflutings have a mean length of 872 metres (min $315 \mathrm{~m}$, max $1772 \mathrm{~m}$ ). Drumlin uplands also occur (see the small figure in Fig. 6). 
The west-northwest to east-southeast orientated drumlins and megaflutings in the lower altitudes consist of highly variable 'hybrid bed', which is a mixture of hard and soft beds. At the top of the hills, the sediment layer is thin and ice has carved the bedrock and shaped rock drumlins (see red lines in Fig. 6).

There are several small flutings in the upland areas where sediment is scarce. The mean length of the flutings is 153 metres ( $\min 33 \mathrm{~m}$, max $760 \mathrm{~m}$ ). Some through valleys were also formed when the ice-sediment mixture scoured out bedrock crevices.

\subsubsection{Interpretation}

The main ice flow direction was from westnorthwest to east-southeast. However, not every formation was deposited parallel to the ice flow. Two different ice flow directions can be distinguished from lineation data: one more westerly and one more northerly. It seems that bedrock knolls and topography affected ice flow locally, deflecting it around hills to form sub-ice lobe formations.

Orientation data further indicate that there was also an older ice flow phase from west-southwest to east-northeast. Formations exhibiting this orientation represent an old flow stage, during which ice flowed towards the White Sea. These old megaflutings have later been drumlinised and reoriented by the latest ice flow to form palimpsests.

\subsection{Inset 4: Sotkamo, Kainuu}

\subsubsection{Description}

Inset area 4 (Fig. 7) is situated in the central region of the NKIL/OIL. Its highest hills are over $300 \mathrm{~m}$ asl, with lowlands at around 140-160 m asl. With strong faults in the area, a north-south orientated quartzite escarpment (as in inset area 2) dominates the landscape. Bedrock around the quartzite consists of migmatite gneiss, pegmatite granite and gabbro in the east, and greywacke, schists and conglomerate in the west. Large lake areas are situated on both sides of the quartzite (water level at $145 \mathrm{~m}$ asl in the west, $137 \mathrm{~m}$ asl in the east).

Sediment thickness varies between lowland areas and the top of the escarpment. The mean length of drumlins, flutings and megaflutings is 397 metres ( $\min 88 \mathrm{~m}$, max $1013 \mathrm{~m}), 112$ metres $(\min 28 \mathrm{~m}, \max 365 \mathrm{~m})$ and 825 metres (min 265 $\mathrm{m}, \max 2864 \mathrm{~m}$ ) respectively. Small flutings are the dominating features of the uplands, drumlins and megaflutings of the lowlands.

\subsubsection{Interpretation}

The northwest-southeast orientated MSGL landforms, megaflutings and drumlins, lie on the lee sides of the hills in the topographically lower softbed areas. Where the highest hills are located, there are hardly any lineations on top of rocks, indicating a local hard-bed sluggish ice-flow environment. At some points, flutings (or grooves) are stencilled to the quartzite (Fig. 7, inset A). Some rock drumlins seem to have been formed by erodent streams, which flowed parallel to fault directions. These can be seen clearly at the top of the hills. Bedrockcontrolled angled drumlins have also been formed (see Fig. 7, inset B). In addition, several northwestsoutheast orientated through valleys were formed when the ice sheet cut its way through the quartzite hills.

\subsection{Inset 5: Lieksa, Eastern Finland}

\subsubsection{Description}

Inset area 5 (Fig. 8) is situated in eastern Finland. The highest hills in the area rise up to $240-250 \mathrm{~m}$ asl. The bedrock consists of migmatite gneiss and tonalite. A relatively large lake basin, Lake Viekijärvi (water level ca $94 \mathrm{~m}$ asl), is situated in the western part of the study area.

Megaflutings and drumlins have been formed in the lowlands area on the lee sides of massive bedrock hills, where the soft sediment bed is thick. The largest megaflutings are almost $3 \mathrm{~km}$ long 


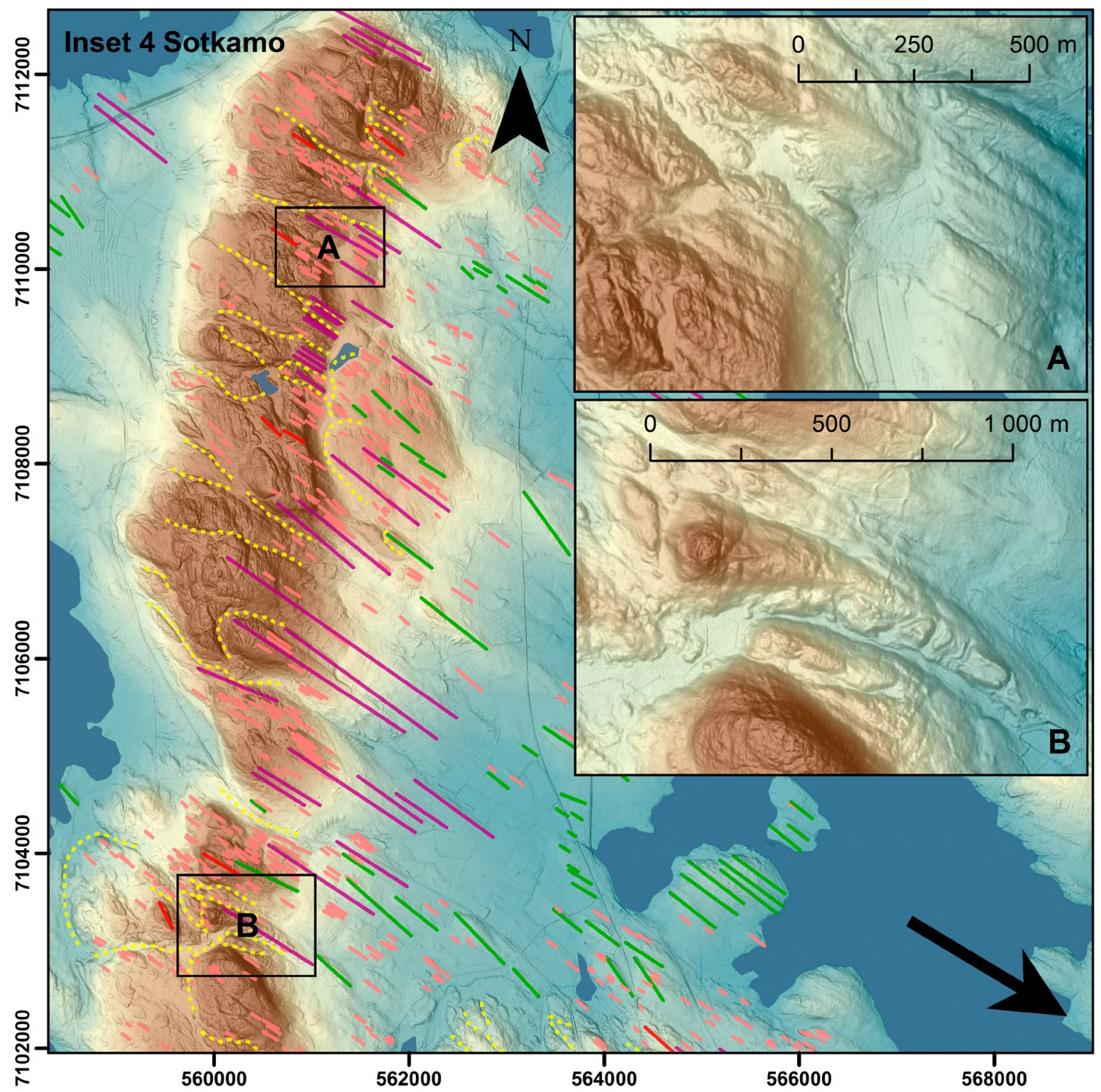

Figure 7. Inset 4, Sotkamo. For legend see Figure 4 or 6 .

(mean length $944 \mathrm{~m}$, min $137 \mathrm{~m}$, max $2963 \mathrm{~m}$ ) and very narrow (ca 10-30 m wide) (Fig. 8, inset B). Drumlins are also long, 391 metres on average ( $\min 57 \mathrm{~m}, \max 2215 \mathrm{~m}$ ). Drumlins north of Lieksa (Hämeensuo (Figure 8, inset A), Luusua, Kankaala) are also rounded. Small flutings and through valleys are the dominating features of the hard-bed areas and bedrock hills. The mean length of flutings in these areas is 93 metres ( $\min 19 \mathrm{~m}, \max 1023 \mathrm{~m}$ ).

MSGLs in the area are mostly northwestsoutheast orientated. The orientation of small flutings on the flanks of the hills somewhat follow the long axes of bedrock hills. 


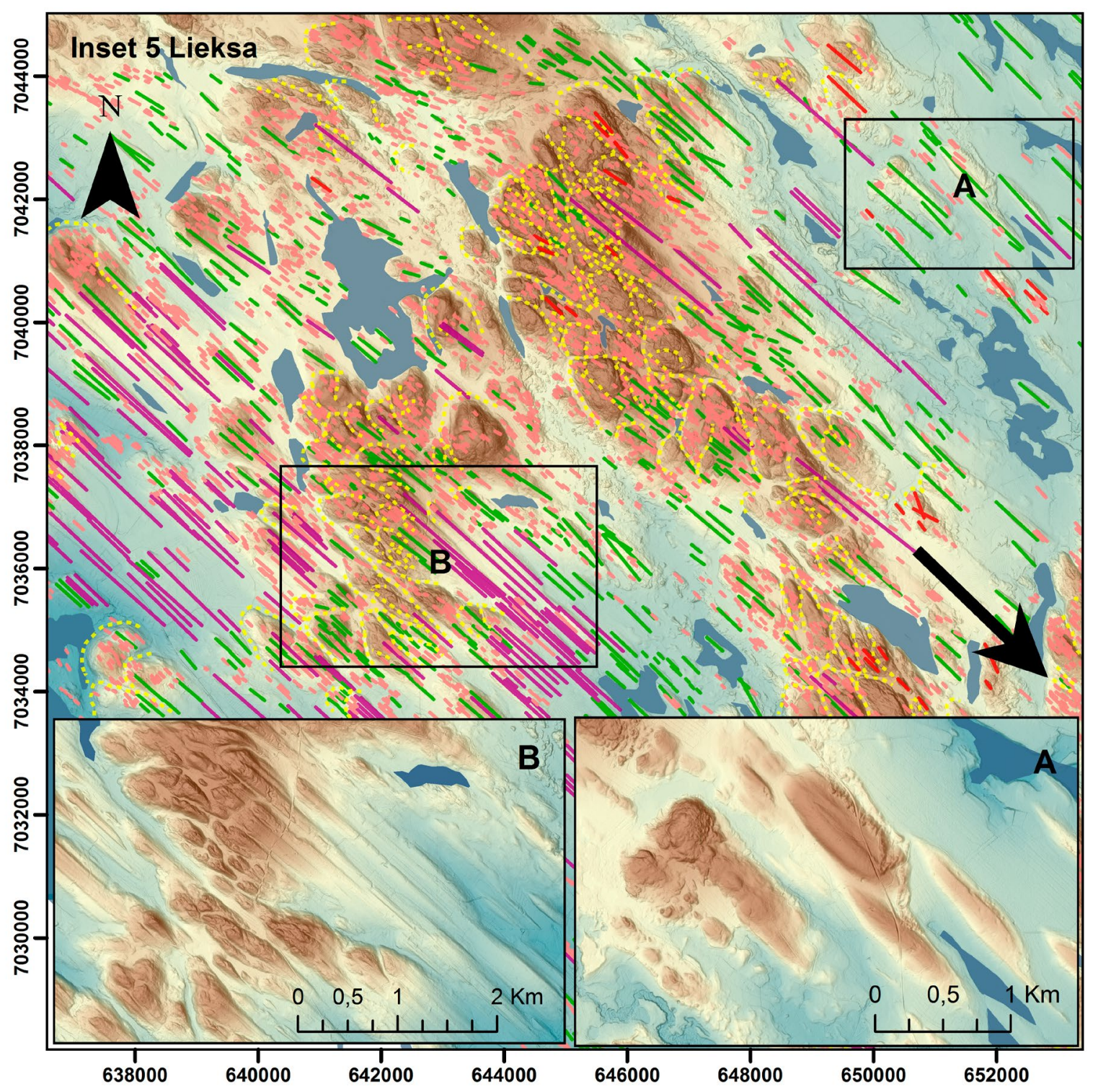

Figure 8. Inset 5, Lieksa. For legend see Figure 4 or 6.

\subsubsection{Interpretation}

It is likely that a relatively coarse erodent stream transported a large amount of sediment downstream during the formation of area 5's MSGL landscape. This indicates fast ice flow under a soft bed and a wet-based glacier, which most probably existed in the eastern side of Lake Viekijärvi. Between the area's hills, an erodent stream under the ice would have been eroding a great number of sizeable through valleys across the tonalite and migmatite gneiss bedrock. These through valleys form a network through and between bedrock knobs.

The orientation of some of the lineations in the north deviates markedly from the rest of the area's dominant orientation pattern. The linear 


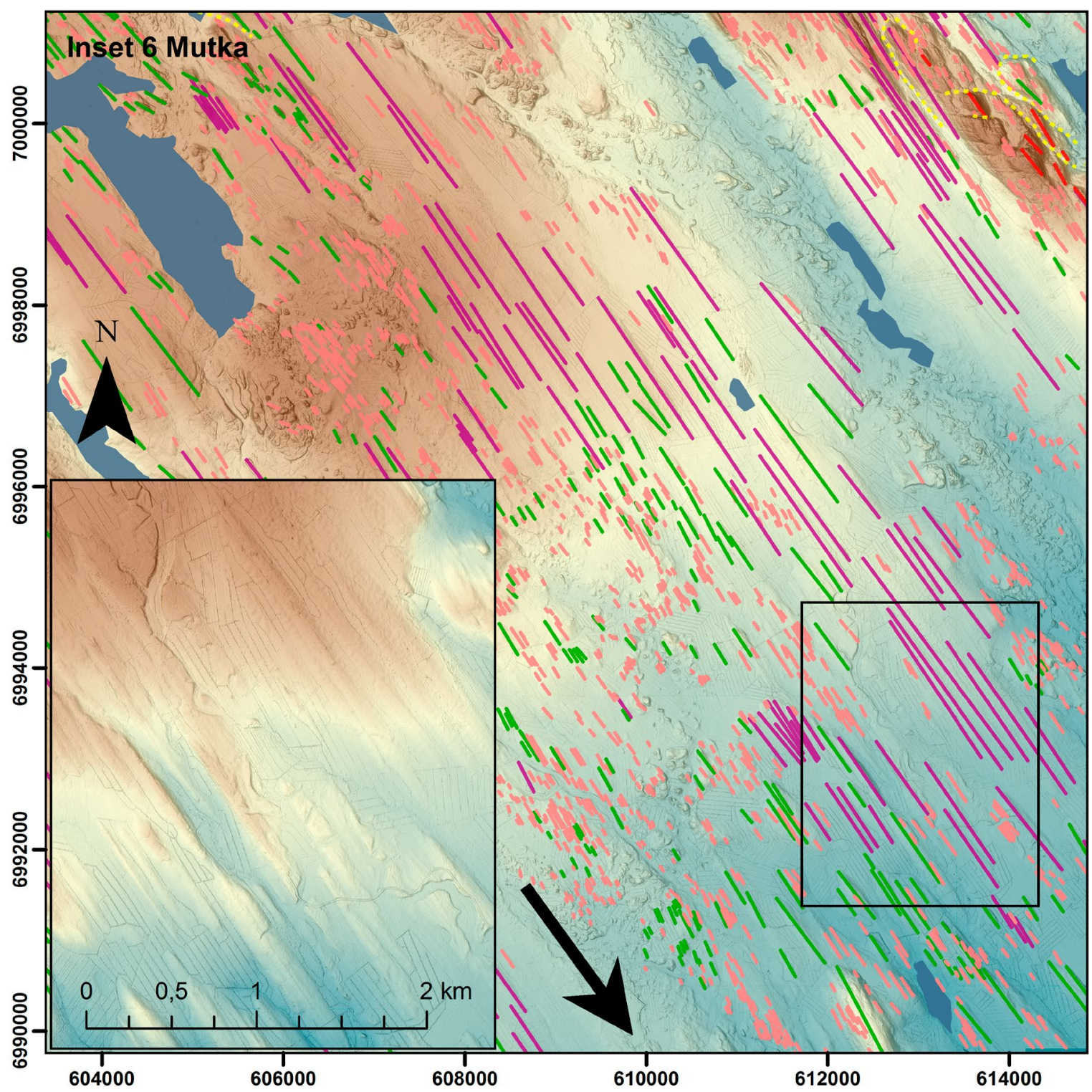

Figure 9. Inset 6, Mutka. For legend see Figure 4 or 6.

directional deviations in the north were caused by a large bedrock escarpment, which steered the ice flow, whereas MSGLs on the lee sides of the obstacles show the dominant direction (northwest to southeast) of the ice flow in the area.

\subsection{Inset 6: Mutka, Eastern Finland}

\subsubsection{Description}

Inset area 6 (Fig. 9) is situated in central eastern Finland. Its general topography is relatively smooth. The altitude of the area rises from 120-140 m asl in the southeastern lowlands to $230-240 \mathrm{~m}$ asl in the 
northwestern uplands. There are no steep bedrock hills in the region, bar one relatively small quartzite hill in the northeast. Bedrock in the southern and eastern parts of area consists of mica schist, gneiss and greywacke. Serpentinite and gabbro also occur in the southwest and quartzite and dolomite in the northwest.

Sediment cover is thick throughout the area. Long megaflutings have been formed in the lowlands (see a smaller figure within Fig. 9). The lengths of the longest megaflutings are ranging 2 to $3 \mathrm{~km}$ with widths estimated as only a couple of dozens of metres. The mean length of all megaflutings is $1034 \mathrm{~m}(\min 290 \mathrm{~m}, \max 2753 \mathrm{~m})$. Drumlins in the area are also long ( $\min 48 \mathrm{~m}$, max $2110 \mathrm{~m}$ ), narrow and smooth (and not overly rounded). The mean length of the drumlins is 292 metres. Small flutings are common, especially in the uplands area. Their mean length is 104 metres (min $20 \mathrm{~m}$, max $469 \mathrm{~m}$ ).

The main orientation of the megaflutings is from northwest to southeast, though some formations have a more northern orientation, from north-northwest to south-southeast.

\subsubsection{Interpretation}

The long megaflutings formed in the topographically smooth lowland soft-bed areas indicate very fast ice flow. In contrast, the drumlins and the small flutings formed in the topographically higher areas in the middle of the inset area 6 indicate more moderate local ice flow velocities. However, drumlins are also very long in this area.

\subsection{Inset 7: Joensuu, Eastern Finland}

\subsubsection{Description}

Inset area 7 (Fig. 10) is situated in eastern Finland, near the southern end of the Kalevala end moraine. The western part of the area is topographically higher than the central part, where the highest bedrock hill rises up to $180 \mathrm{~m}$ asl. The west and the centre differ from the southern and eastern parts (Kalevala end moraine zone area) where the landscape is smooth and the altitudes range between ca $100-120 \mathrm{~m}$ asl. Bedrock in area 7 consists of granodiorite surrounded by mica schist, gneiss and greywacke.

The area is surrounded by large bodies of water: Lake Höytiäinen to the east and Lake Viinijärvi to the west (outside Fig. 10). Water level altitudes of lakes in the area are around $80 \mathrm{~m}$ asl (lower in the west and higher in the east). Two eskers run from the northwest, terminating at the large Kalevala end moraine in the southeast.

The glacially formed landscape is dominated by small flutings. The mean length of the flutings is 70 metres $(\min 16 \mathrm{~m}$, max $513 \mathrm{~m})$. Only few larger streamlined formations, drumlins or megaflutings, have been formed on the lee sides of bedrock obstacles. The mean lengths of drumlins and megaflutings are 215 metres $(\min 62 \mathrm{~m}$, max $866 \mathrm{~m})$ and 415 metres $(\min 257 \mathrm{~m}, \max 529 \mathrm{~m})$ respectively.

\subsubsection{Interpretation}

The flutings indicate an overall main ice flow direction of north-northwest to south-southeast. However, the orientation of the flutings varies on a local scale. Analysing bedrock and the orientation of the flutings and their variable patterns, it can be concluded that bedrock controlled the ice flow on a local scale.

In the smaller picture in Figure 10, lineations on the surface of the glaciofluvial delta deposited at the ice margin during the Kalevala end moraine stage indicate ice re-advance. Accordingly, the small flutings were most likely deposited under a relatively thin glacier (cf. Eyles et al., 2015).

Further, the landscape patterns and some through valleys formed in the bedrock fracture zones indicate strong ice-flow and erosion during the Kalevala flow stage. 


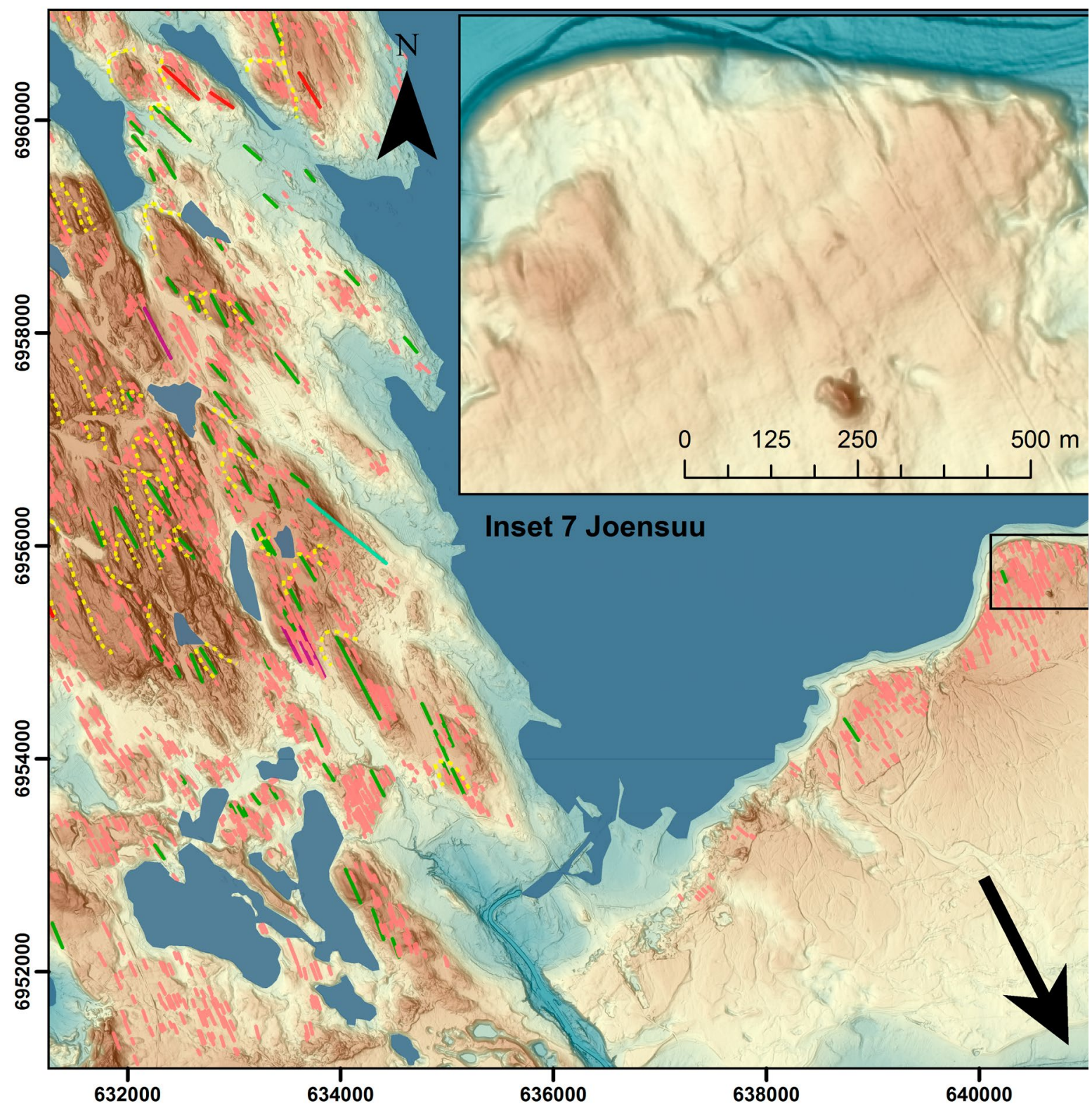

Figure 10. Inset 7, Joensuu. Glacial lineations terminate in the Kalevala end moraine. The Kalevala end moraine consists of deltas and arc shaped small end moraine ridges. For legend see Figure 4 or 6.

\section{Discussion}

This study described and discussed the NKIL/OIL ice flow across central Finland. Glacier dynamics of the NKIL/OIL were studied using principles from the glacial inversion theory, which was deemed to provide the best tools for a simple interpretation of variability in the MSGL landforms (cf. Kleman et al., 1997; Stokes et al., 2005). MSGLs and other subglacial lineation features in the NKIL/OIL area were mapped and their patterns analysed. This data was used to shed light on factors controlling glacial ice flow, such as topography, bedrock, underlying older sediments and subglacial lake basins (cf. 


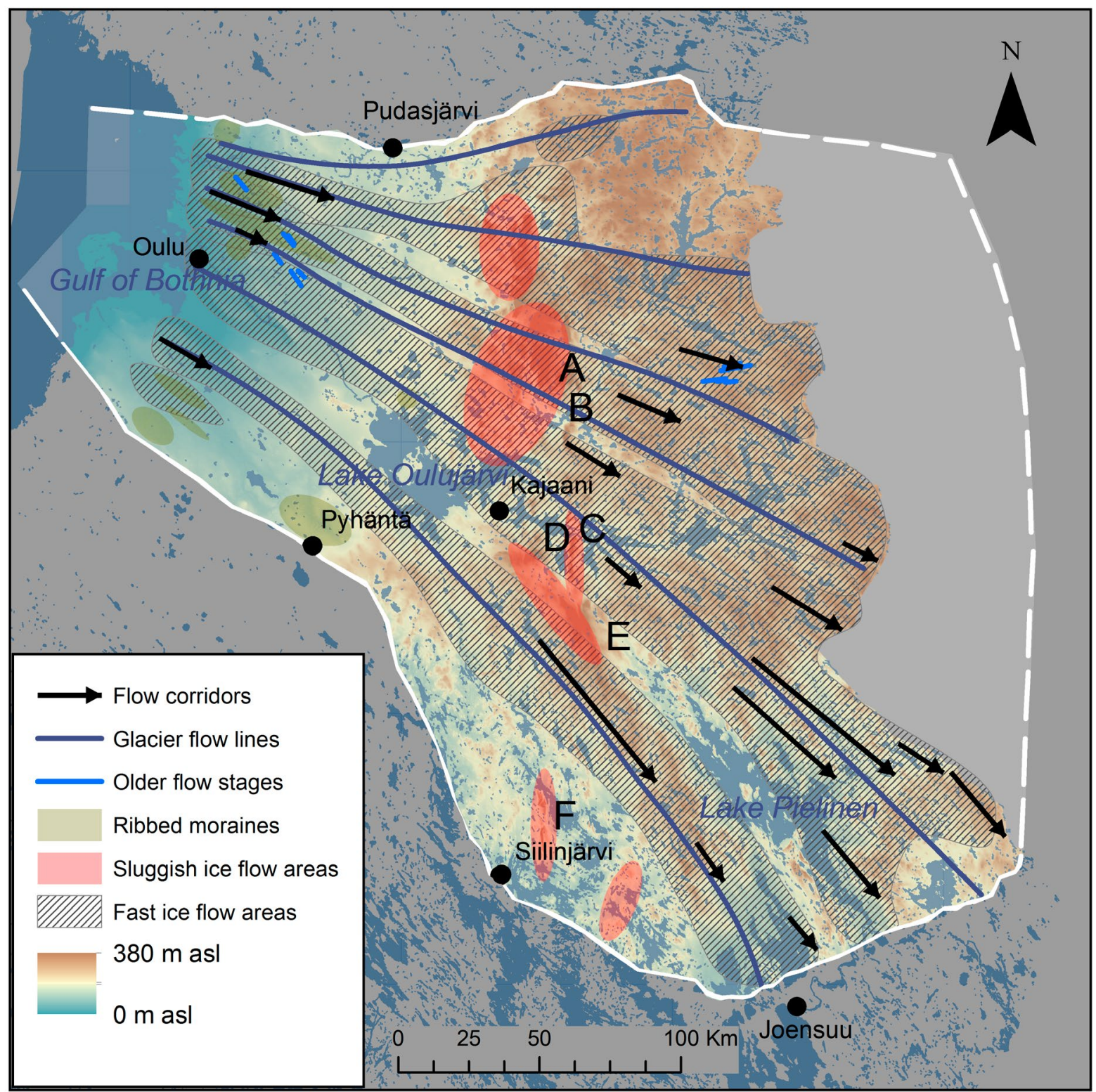

Figure 11. Areas of fast ice flow and flow corridors in the area of NKIL/OIL. Letters A-F indicate MSGL formations in the lee side of bedrock escarpments.

Kleman et al., 1997; Boulton et al., 2001; Stokes \& Clark, 2003; Eyles et al., 2016).

LiDAR DEM imagery and MSGL inventory carried out in the NKIL/OIL area show that local ice flow velocity was mainly controlled by topography and bedrock. On crystalline bedrock escarpment regions, a thin sediment layer on rough bedrock surface maintained hard-bed ice basal conditions.
The lack of MSGLs in those regions is obvious (Fig. 11 ; red raster). In the regions where MSGLs do occur (e.g. lee sides of obstacles), there was enough sediment to lubricate erosional processes, which supports the erodent layer hypothesis and grooveploughing theories (Eyles et al., 2016; Clark et al., 2003) (see Fig. 11). The groove-ploughing theory by Clark et al. (2003) suggests that these kinds of 
elongated MSGLs (in Figs 7 and 8) could have formed onto soft sediments by keels or bumps, which were in the base of the ice sheet.

Thick sediment bed and local depressions often encompass subglacial lakes which then promote fast ice flow (see Fig. 11; arrows pointing towards the terminus). In a MSGL phase, glacier velocity increases from $100 \mathrm{~m} /$ year to over $400 \mathrm{~m} /$ year and an erosional continuum forms a low-friction surface between the glacier base and underlying sediment (Eyles et al., 2016). According to Eyles et al. (2016), these low-friction conditions enable drumlins to evolve into megaflutings.

The results presented here indicate that the most significant ice flow corridors existed in three areas: 1) in eastern Finland (the NKIL area) around Lake Pielinen, 2) in Kainuu, east and southeast of Lake Oulujärvi and 3) in northern Ostrobothnia. These flow corridors, therefore, were in areas where relatively large basins, and maybe thicker layers of sediment, occur. The above factors provided favourable conditions for fast ice flow and for the formation of several lineations. The three main flow corridors were located several tens, or even hundreds, of kilometres away from so-called onset zones with ribbed moraines (see brown raster in Fig. 11). Onset zones are considered to be 50 to $100 \mathrm{~km}$ wide areas where abundant cold based glacier landforms, such as ribbed moraines, are formed amongst narrow corridors of fast moving ice (Kleman \& Hättestrand, 1999; Sarala, 2006). Flow corridors north of Oulu (Fig. 4) are not contemporaneous to other corridors in the NKIL, but were formed much later during the OIL fast glacier flow.

MSGL beds indicating fast ice flow are shown in inset figures 4-10. The MSGL database and ice lobe geometry parametres assembled for this work show that the NKIL/OIL did not form a typical continuum of the terrestrial ice lobe, as these tend to have a narrow trunk with long megafluted beds (cf. Boulton et al., 2001). The NKIL was much wider than previously anticipated and megaflutings were formed within a wide sector across the lobe. The widening of the lobe may also have been partly caused by groove-ploughing mechanisms (Clark et al., 2003). It is plausible that the White Sea Ice Lake (Pasanen et al., 2010) in front of the ice margin (i.e. terminus) in the north, and the Baltic Ice Lake in front of the terminus in the south, controlled the dynamics and the activity of the NKIL.

It should be also noted that the NKIL had different dimensions in space and time, compared to adjacent ice lobes. The Kuusamo ice lobe (KIL) to the north was much smaller and not operating at the time when the NKIL was active, and the activity of the Finnish Lake District Ice Lobe (FLDL) had already ceased.

This paper suggests that these factors (large subglacial lake basins, groove-ploughing mechanism, dynamics of adjacent ice lobes), together with the abovementioned topographical and subglacial settings, were the main reasons the NKIL expanded to be the largest ice lobe in the region, which was earlier covered by the Scandinavian Ice Sheet during the late Younger Dryas.

In the area, megafluted beds extended to the NKIL terminus in the south (see Fig. 10). This finding differs from data from eastern and northeastern parts of the area presented in Putkinen \& Lunkka (2008) and Punkari (1985). In their findings, the terminal zone is characterized by drumlinised bed which represents more conservative ice flow rates, compared to the fast flow rates in the southern region presented here. These slow ice flow/fast ice flow variations are due to different topographical settings in the eastern and northeastern areas, compared to the southern area. In the south, fast ice flow occurred towards the deep ice lake basins which stretched north to the southern terminus. Also, in the southern region, several metres' thick glaciolacustrine sediments lubricated the wet based subglacial deformation - a process which led to even faster ice flow.

As outlined, this paper suggests that the rough 'mixed bed' conditions at the ice-bedrock interface in the Kalevala-Kostamus sector - compared to the wet based soft-bed conditions of the southern sector - were the main reasons for different ice lobe behaviour in different parts of the NKIL. 
Although in palaeoglacier dynamic research it is important to tie ice flow systems to time, this study has not been able to answer questions of timings of separate ice flow dynamic stages. However, it is evident that the NKIL behaved in a similar manner to its counterparts in southern Finland, which were controlled by climatic events during the Younger Dryas.

\section{Conclusions}

The main conclusions from the results are:

1. Topographical and bedrock factors, together with pre-existing sediment cover and lake basins, were the main factors affecting the dynamics of the NKIL/OIL. The results indicate that the NKIL/OIL operated through several major flow corridors.

2. A large amount of sediment was eroded from terrain and deposited to the Kalevala end

\section{References}

Aario, R., 1977. Classification and terminology of morainic landforms in Finland. Boreas 6, 87-100. https://doi.org/10.1111/j.1502-3885.1977.tb00338.x

Aario, R. \& Forsström, L., 1979. Glacial stratigraphy of Koillismaa and North Kainuu, Finland. Fennia 157:2 $1-49$.

Benn, D.I. \& Evans, D.J.A., 2010. Glaciers and Glaciation. Hodder Education, London, $2^{\text {nd }}$ Ed., 802 p.

Boulton, G.S., Dongelmans, P., Punkari, M. \& Broadgate, M., 2001. Palaeoglaciology of an ice sheet through a glacial cycle: the European ice sheet through the Weichselian. Quaternary Science Reviews 20, 591-625. https://doi.org/10.1016/S0277-3791(00)00160-8

Boulton, G.S. \& Zatsepin, S., 2006. Hydraulic impacts of glacier advance over a sediment bed. Journal of glaciology 52, 497-527. https://doi.org/10.3189/172756506781828403

Clark, C.D., 2010. Emergent drumlins and their clones: from till dilatancy to flow instabilities. Journal of Glaciology 56, 1011-1025. https://doi.org/10.3189/002214311796406068

Clark, C.D., Tulaczyk, S.M., Stokes, C.R. \& Canals, M., 2003. A groove-ploughing theory for the production of megascale glacial lineations, and implications for ice-stream mechanics. Journal of Glaciology 49, 240-256. https://doi.org/10.3189/172756503781830719 moraine zone. The Erodent Layer Hypothesis explains erosion and transportation mechanisms but this paper's results indicate that they are more complex than previously thought.

3. Preliminary results suggest that the NKIL/ OIL did not operate through a single surge mechanism, but with several retreat and readvance cycles throughout its life span. Future work will reveal how many of these cycles, and different ice flow stages occurred during the life span of the NKIL/OIL.

\section{Acknowledgements}

The authors would like to thank the reviewers John Maclachlan and Chris D. Clark for their helpful and constructive feedback and comments on the manuscript. We also thank the GTK's mapping team and 3D laboratory staff for their help during the project.

Donner, J., 1995. The Quaternary history of Scandinavia. Cambridge University Press, 200 p.

Ekman, I. \& Iljin, V., 1991. Deglaciation, the Younger Dryas end moraines and their correlation in the Karelian A. S. S. R and adjacent areas. In: Rainio, H. \& Saarnisto, M. (eds.), Eastern Fennoscandian Younger Dryas end moraines: field conference, North Karelia, Finland - Karelian ASSR, June 26 - July 4, 1991. Geological Survey of Finland, Excursion guide 32, 73-99.

Eyles, N., Boyce, J.I. \& Putkinen, N., 2015. Neoglacial (<3000 years) till and flutes at Saskatchewan Glacier, Canadian Rocky Mountains, formed by subglacial deformation of a soft bed. Sedimentology 62, 182-203. https://doi.org/.1111/sed.12145

Eyles, N., Putkinen, N., Sookhan, S. \& Arbelaez-Moreno, L., 2016. Erosional origin of drumlins and megaridges. Sedimentary Geology 338, 2-23. https://doi.org/10.1016/j.sedgeo.2016.01.006

Fowler, A.C., 2010. The instability theory of drumlin formation applied to Newtonian viscous ice of finite depth. Proceedings of the Royal Society A 466, 2673-2694. https://doi.org/10.1098/rspa.2010.0017

Kleman, J., Hättestrand, C., Borgström, I. \& Stroeven, A., 1997. Fennoscandian palaeoglaciology reconstructed using a glacial geological inversion model. Journal of Glaciology 43, 283-299.

https://doi.org/10.3198/1997JoG43-144-283-299 
Kleman, J. \& Hättestrand, C., 1999. Frozen-bed Fennoscandian and Laurentide ice sheets during the Last Glacial Maximum. Nature 402, 62-66. https://doi.org/10.1038/47005

Larsen, E., Kjær, K. H., Demidov, I. N., Funder, S., Grøsfjeld, K., Houmark-Nielsen,M., Jensen, M., Linge, H. \& Lyså, A., 2006. Late Pleistocene glacial and lake history of northwestern Russia. Boreas 35, 394-424. https://doi.org/10.1080/03009480600781958

Lehtinen, M., Nurmi, P. \& Rämö, T., (eds.), 1998. Suomen kallioperä: 3000 vuosimiljoonaa. Helsinki, The Geological Society of Finland, 375 p. (in Finnish)

Lunkka, J.P., Saarnisto, M., Gey, V., Demidov, I. \& Kiselova, V., 2001. Extent and age of the Last Glacial Maximum in the southeastern sector of the Scandinavian Ice Sheet. Global and Planetary Change 31, 407-425. https://doi.org/10.1016/S0921-8181(01)00132-1

Lunkka, J.P., Putkinen, N. \& Miettinen, A., 2012. Shoreline displacement in the Belomorsk area, NW Russia during the Younger Dryas Stadial. Quaternary Science Reviews 37, 26-37.

https://doi.org/10.1016/j.quascirev.2012.01.023

Möller, P. \& Dowling, T.P.F., 2016. Streamlined subglacial bedforms on the Närke plain, south-central Sweden - Areal distribution, morphometrics, internal architecture and formation. Quaternary Science Reviews 146, $182-215$.

https://doi.org/10.1016/j.quascirev.2016.04.007

Ojala, A.E.K., Palmu, J.-P., Åberg, A., Åberg, S. \& Virkki. H., 2013. Development of an ancient shoreline database to reconstruct the Litorina Sea maximum extension and the highest shoreline of the Baltic Sea basin in Finland. Bulletin of the Geological Society of Finland 85, 127144.

Pasanen, A., Lunkka, J.P. \& Putkinen, N., 2010. Reconstruction of the White Sea Basin during the late Younger Dryas. Boreas 39, 273-285. https://doi.org/10.1111/j.1502-3885.2009.00128.x

Punkari, M., 1980. The ice lobes of the Scandinavian ice sheet during the deglaciation in Finland. Boreas 9, 307-310. https://doi.org/10.1111/j.1502-3885.1980.tb00710.x

Punkari, M., 1985. Glacial geomorphology and dynamics in Soviet Karelia interpreted by means of satellite imagery. Fennia 163:1, 113-153.

Punkari, M., 1997. Glacial and glaciofluvial deposits in the interlobate areas of Scandinavian Ice Sheet. Quaternary Science Reviews 16, 741-753. https://doi.org/10.1016/S0277-3791(97)00020-6

Punkari, M. \& Boulton, G.S., 1995. Skandinavian mannerjäätikön itäosan dynamiikka ja reuna-asemat Nuoremman Dryaksen aikana (The dynamics and marginal positions of the Scandinavian ice sheet in its eastern part during the Younger Dryas stadial). Terra 107, 3-14.

Putkinen. N., 2011. Late Weichselian deglaciation chronology and palaeoenvironments in northern Karelia, NW Russia. Geological Survey of Finland, Espoo, 21 p.

Putkinen, N. \& Lunkka, J.P., 2008. Ice stream behaviour and deglaciation of the Scandinavian Ice Sheet in the Kuittijärvi area, Russian Karelia. Bulletin of the Geological Society of Finland 80, 19-37.

Putkinen, S., Putkinen, N., Eyles, N., Ojala, A.E.K., Palmu, J.P., Sarala, P., Väänänen, T., Räisänen, J., Rauhaniemi, T., Ahtonen, N. \& Kiiskinen, A., 2017. High-resolution LiDAR mapping of glacial landforms and ice streams in Finland. Bulletin of Geological Society of Finland (in press, this volume).

Rainio, H., 1995. Large ice-marginal formations and deglaciation in southern Finland. In: Ehlers, J., Kozarski, S. \& Gibard, P. (eds.) Glacial deposits in North-East Europe. A.A. Balkema, Rotterdam, 57-66.

Ravier, E., Buoncristiani, J.F., Guiraud, M., Menzies, J., Clerc, S., Goupy, B. \& Portier, E., 2014. Porewater pressure control on subglacial soft sediment remobilization and tunnel valley formation: a case study from the Alnif tunnel valley (Morocco). Sedimentary Geology 304, 71-95. https://doi.org/10.1016/j.sedgeo.2014.02.005

Sarala, P., 2006. Ribbed moraine stratigraphy and formation in southern Finnish Lapland. Journal of Quaternary Science 21,387-398.

https://doi.org/10.1002/jqs.995

Stokes, C.R. \& Clark, C.D., 2003. The Dubawnt Lake palaeoice stream: Evidence for dynamic ice sheet behavior on the Canadian Shield and insights regarding the controls on ice-stream location and vigour. Boreas 32, 263-279. https://doi.org/10.1111/j.1502-3885.2003.tb01442.x

Stokes, C.R., Clark, C.D., Darby, D.A. \& Hodgson, D.A., 2005 Late Pleistocene ice export events into the Arctic Ocean from the M'Clure Strait Ice Stream, Canadian Arctic Archipelago. Global and Planetary Change 49, 139-162. https://doi.org/10.1016/j.gloplacha.2005.06.001

Stokes, C.R., Clark, C.D., Lian, O.B. \& Tulaczyk, S., 2007. Ice stream sticky spots: a review of their identification and influence beneath contemporary and palaeo-ice streams. Earth Science Reviews 81, 217-249. https://doi.org/10.1016/j.earscirev.2007.01.002

Stokes, C.R., Spagnolo, M., Clark, C.D., Ó Cofaigh, C., Lian, O.B. \& Dunstone, R.B., 2013. Formation of mega-scale glacial lineations on the Dubawnt Lake Ice Stream bed: 1. size, shape and spacing from a large remote sensing dataset. Quaternary Science Reviews 77, 190-209. https://doi.org/10.1016/j.quascirev.2013.06.003

Svendsen, J.I., Alexanderson, H., Astakhov, V.I., Demidov, I., Dowdeswell, J.A., Funder, S., Gataullin, V., Henriksen, M., Hjort, C., Houmark-Nielsen, M., Hubberten, H.W., Ingólfsson, Ó., Jakobsson, M., Kjær, K.H., Larsen, E., Lokrantz, H., Lunkka, J.P., Lyså, A., Mangerud, J., Matiouchkov, A., Murray, A., Möller, P., Niessen, F., Nikolskaya, O., Polyak, L., Saarnisto, M., Siegert, C., Siegert, M.J., Spielhagen, R.F. \& Stein, R., 2004. Late Quaternary ice sheet history of northern Eurasia. In: Quaternary environments of the Eurasian North (QUEEN). Quaternary Science Reviews 23, 1229-1271. https://doi.org/10.1016/j.quascirev.2003.12.008 